\title{
Angiotensin II infusion in COVID-19- associated vasodilatory shock: a case series
}

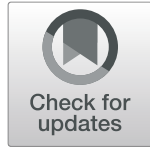

\author{
Alberto Zangrillo ${ }^{1}$, Giovanni Landoni ${ }^{1 *}$, Luigi Beretta ${ }^{1}$, Federica Morselli ${ }^{1}$, Ary Serpa Neto ${ }^{2,3}$, \\ Rinaldo Bellomo $2,4,5,6$ (D) and the COVID-BioB Study Group
}

Two thirds of ventilated COVID-19 patients require vasopressor support [1]. Recommended vasopressors include norepinephrine and vasopressin. Recently, based on a randomized trial [2], angiotensin II (ANGII) was FDA- and EMA-approved for catecholamine-resistant vasodilatory shock. ANGII use as primary vasopressor for vasodilatory shock has never been reported, let alone for COVID-19associated vasodilatory shock. ANGII may be logical in this setting. It specifically assists patients recently exposed to angiotensin-converting enzyme inhibitors [2,3] and increases the internalization and downregulation of angiotensinconverting enzyme 2 [4], the receptor for COVID-19. Its use may also inform the debate about the risks and benefits of angiotensin receptor blockers in COVID-19-infected patients [5]. In this pilot compassionate-use case series, we used ANGII either as primary or rescue vasopressor in ventilated patients with COVID-19-associated vasodilatory shock and assessed the course of key physiological variables during the first $48 \mathrm{~h}$ of treatment.

We studied a cohort of consecutive ventilated patients in COVID-19-dedicated ICUs at San Raffaele Scientific Institute, Milan, Italy. Patients had vasodilatory shock and COVID-19-related infection (positive viral RNA biospecimen and typical clinical and radiological features). The Ethics Committee approved compassionate use of the drug.

All cases received commercial ANGII (Giapreza ${ }^{\circ}$, La Jolla San Diego, CA) as continuous infusion started at $20 \mathrm{ng} / \mathrm{kg} /$ min and titrated to a MAP target $>65 \mathrm{mmHg}$. We collected key data before and during $48 \mathrm{~h}$ of angiotensin II infusion.

Over 6 days (March 12 to March 18, 2020) we treated 16 patients, 10 with ANGII as first-line agent, five as second-line agent (Table 1), and one patient with

\footnotetext{
* Correspondence: landoni.giovanni@hsr.it

'Department of Anesthesia and Intensive Care, IRCCS San Raffaele Scientific Institute, Via Olgettina 60, 20132 Milano, Italy

Full list of author information is available at the end of the article
}

unobtainable data. ANGII dose was relatively constant. MAP and urine output remained stable; lactate and creatinine increased and $\mathrm{C}$-reactive protein decreased (Table 1). However, the $\mathrm{SpO}_{2} / \mathrm{FiO}_{2}$ ratio increased significantly with a decrease in $\mathrm{FiO}_{2}$ and PEEP (Fig. 1). At latest follow-up (1 week), 14 patients were alive.

In ventilated patients with COVID-19-associated vasodilatory shock, we assessed the initial physiological changes associated with ANGII infusion as primary or rescue vasopressor. Overall, the administration of ANGII was associated with achievement and maintenance of target MAP, an increase on $\mathrm{SpO}_{2} / \mathrm{FiO}_{2}$ ratio, and a decrease in $\mathrm{FiO}_{2}$. These oxygenation improvements were significant.

This represents the first experience with ANGII in COVID-19-associated vasodilatory shock and with ANGII as primary vasopressor in humans. The findings are consistent with those of a previous trial and subsequent subgroup [2] and ANG I/II ratio-related analyses [3]. They suggest the absence of early physiologically harm and improved oxygenation with ANG II.

The key limitations of this study are obvious. It is single-center, small, observational in nature; lacks a control population; and is open-label. However, in this pandemic setting, the ethics of ensuring compassionate drug use to all patients were considered a priority. Moreover, before considering controlled trials, evidence of some physiological safety was considered important. Finally, under the extraordinary pressures of the most dramatic health disaster in Italy's history in a century, this study was the best possible under the circumstances.

In conclusion, we provide the first observational cohort study of ANGII infusion in ventilated patients with COVID-19-associated vasodilatory shock. Our findings provide preliminary evidence to assist clinicians in their choice of vasopressors and justify and help design future controlled studies. 
Table 1 Baseline characteristics and physiological changes in treated patients

\begin{tabular}{|c|c|c|c|}
\hline & $\begin{array}{l}\text { Baseline } \\
(\boldsymbol{n}=15)\end{array}$ & $\begin{array}{l}\text { After } 24 \mathrm{~h} \\
(\boldsymbol{n}=15)\end{array}$ & $\begin{array}{l}\text { After } 48 \mathrm{~h} \\
(\boldsymbol{n}=15)\end{array}$ \\
\hline Age, years & $64(54-69)$ & - & - \\
\hline Male gender & $11(73.3)$ & - & - \\
\hline Angiotensin II as first-line agent & $10(66.7)$ & - & - \\
\hline Angiotensin II dose, ng/kg/min & $20.0(5.0-20.0)$ & $20.0(8.4-20.8)$ & $20.0(8.1-20.8)$ \\
\hline \multicolumn{4}{|l|}{ Support and drugs } \\
\hline High dose catecholamine (>0.25 $\mu \mathrm{g} / \mathrm{kg} / \mathrm{min})$ & $1(6.7)$ & - & - \\
\hline Receiving catecholamine $>12 \mathrm{~h}$ & $2(13.3)$ & - & - \\
\hline Prone positioning & $5(41.7)$ & $11(78.6)$ & $11(78.6)$ \\
\hline Use of tocilizumab & $5(35.7)$ & - & - \\
\hline Norepinephrine dose, $\mu \mathrm{g} / \mathrm{kg} / \mathrm{min}$ & $0.10(0.10-0.20)$ & $0.02(0.00-0.09)$ & $0.01(0.00-0.14)$ \\
\hline Hours using before & $8.5(1.8-15.8)$ & - & - \\
\hline \multicolumn{4}{|l|}{ Vital signs at start } \\
\hline Systolic arterial pressure, $\mathrm{mmHg}$ & $110(95-115)$ & $110(105-129)$ & $120(115-120)$ \\
\hline Diastolic arterial pressure, mmHg & $60(52-64)$ & $60(56-64)$ & $70(59-70)$ \\
\hline Mean arterial pressure, $\mathrm{mmHg}$ & $71(65-79)$ & $77(76-80)$ & $85(80-87)$ \\
\hline Heart rate, bpm & $82(70-92)$ & $72(68-83)$ & $71(66-76)$ \\
\hline Atrial fibrillation & $1(7.1)$ & - & - \\
\hline Cumulative urine output, $\mathrm{mL}$ & $237.5(71.2-365.0)$ & $620.0(385.0-750.0)$ & $727.0(470.0-1050.0)$ \\
\hline Oliguria & $3(30.0)$ & - & - \\
\hline \multicolumn{4}{|l|}{ Ventilatory support } \\
\hline $\mathrm{FiO}_{2}$ & $0.70(0.61-0.70)$ & $0.50(0.40-0.60)$ & $0.40(0.36-0.54)$ \\
\hline PEEP, $\mathrm{cmH}_{2} \mathrm{O}$ & $14(12-15)$ & $12(10-12)$ & $11(10-14)$ \\
\hline $\mathrm{SpO}_{2}, \%$ & 97 (94-99) & $98(96-98)$ & $97(91-98)$ \\
\hline $\mathrm{PaO}_{2} / \mathrm{FiO}_{2}$ & $121.4(98.1-218.1)$ & $195.2(148.3-245.0)$ & $200.0(168.0-248.5)$ \\
\hline $\mathrm{SpO}_{2} / \mathrm{FiO}_{2}$ & $140.7(132.5-150.6)$ & 191.5 (118.4-258.0) & $193.8(142.2-235.9)$ \\
\hline \multicolumn{4}{|l|}{ Laboratory tests at start } \\
\hline Lactate, mmol/L & $1.49(1.36-1.56)$ & $1.72(1.58-2.00)$ & $1.83(1.53-2.15)$ \\
\hline Creatinine, mg/dL & $1.00(0.85-1.68)$ & $1.69(1.16-2.38)$ & $1.69(1.06-2.43)$ \\
\hline C-reactive protein, mg/dL & $232.3(165.4-269.2)$ & $202.0(148.4-231.1)$ & $115.0(95.0-190.4)$ \\
\hline White blood cell count, $\times 1000$ cells $/ \mathrm{mm}^{3}$ & $11.9(7.7-13.2)$ & $10.1(6.2-12.4)$ & $9.2(7.2-14.2)$ \\
\hline Lymphocyte count, $\times 1000$ cells $/ \mathrm{mm}^{3}$ & $5.30(3.05-16.222)$ & $7.90(3.70-12.85)$ & $8.30(5.20-13.50)$ \\
\hline
\end{tabular}



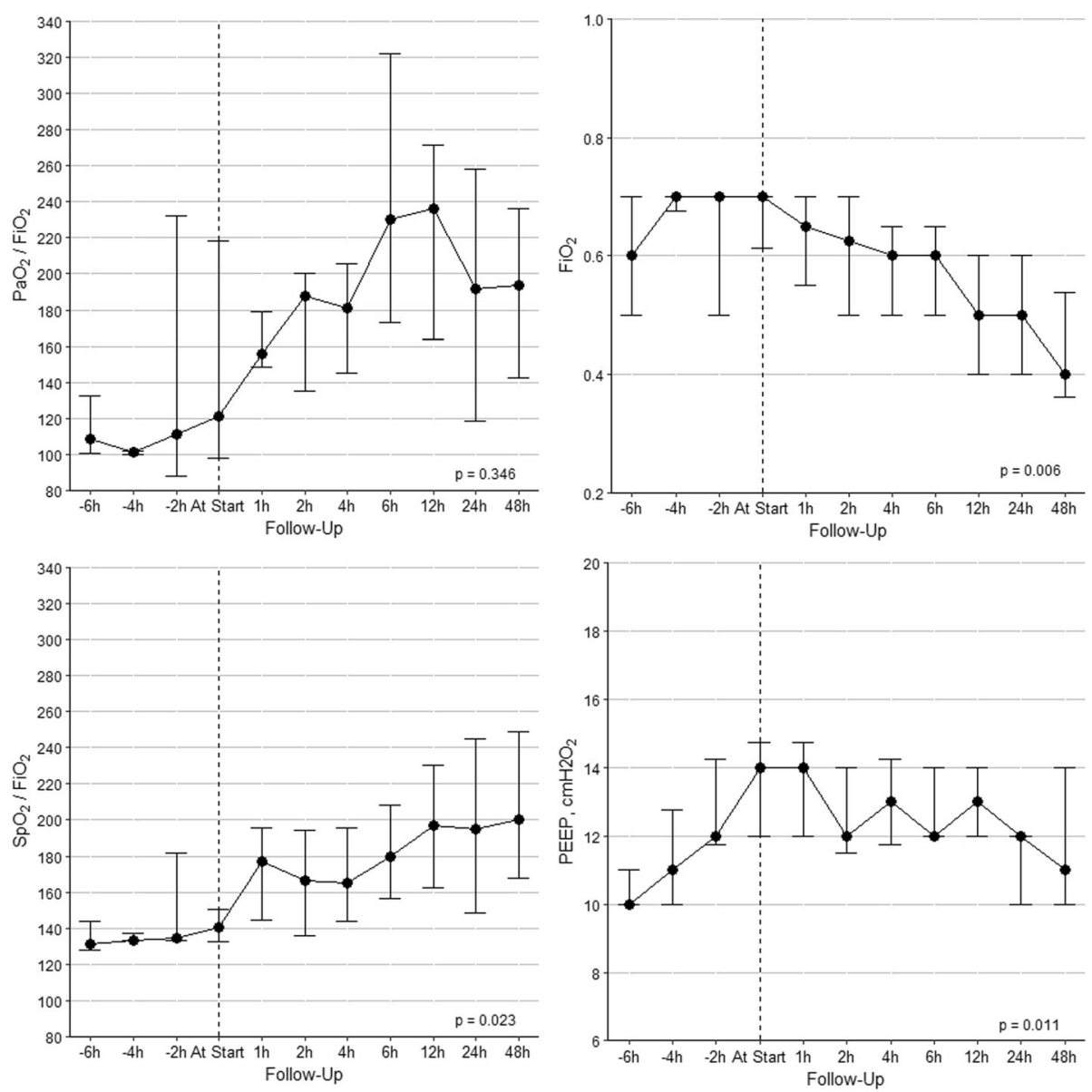

Fig. 1 Changes in oxygenation parameters in the first $48 \mathrm{~h}$ of angiotensin II infusion. Data are median and quartile 25\% to quartile $75 \%$. The changes in the parameters over time were assessed with a mixed-effect quantile model based on the asymmetric Laplace distribution ( $\tau=0.50$, a median regression), taking into account repeated measurements and considering the time of measurements (as a continuous variable) as fixed effect. The $p$ value in the graphs represents the changes over this time. In all models, only values at and after the start of the infusion drug were taken into account, and the values before the start were used only for graphic purpose. All results were confirmed after bootstrapping with 10,000 replications. All analyses were conducted in R (R Foundation), version 3.6.3

\section{Acknowledgements}

Collaborating author names from COVID-BioB Study Group:

Anna Mara Scandroglio MD

Sergio Colombo, MD ${ }^{1}$

Antonio Dell'Acqua, MD ${ }^{1}$

Paolo Silvani, MD ${ }^{1}$

Evgeny Fominskiy, MD ${ }^{1}$

Giacomo Monti, MD ${ }^{1}$

Maria Luisa Azzolini, MD ${ }^{1}$

Antonio Bellantoni, MD ${ }^{1}$

Cristina Barberio, MD

Gabriele Valsecchi, MD ${ }^{1}$

Omar Saleh, MD ${ }^{1}$

Gaetano Lombardi, MD

Moreno Tresoldi, MD

Paolo Scarpellini, MD

Lorenzo Dagna, MD ${ }^{1}$

Fabio Ciceri, MD

Yanase Fumitaka, MD²

Affiliations

1 Department of Anesthesia and Intensive Care, IRCCS San Raffaele Scientific Institute, Milan, Italy

2 Department of Intensive Care, Austin Hospital, Melbourne, Australia

\section{Authors' contributions}

Concept: AZ, GL, and RB. Data collection: AZ, GL, LB, and FM. Data cleaning and statistical analysis: GL and ASN. Manuscript preparation: $A Z, G L, A S N$ and RB. Administrative support: AZ, GL, and RB. The authors read and approved the final manuscript

\section{Funding}

None

\section{Availability of data and materials}

Full de-identified dataset and codes of the analyses are available upon request to the corresponding authors.

Ethics approval and consent to participate

Ethical Committee approved the compassionate use of the study drug for this study (which is approved by European Medical Association [EMA], but not yet commercialized).

\section{Consent for publication}

Not applicable.

Competing interests

The authors declare that they have no competing interest. 


\section{Author details}

Department of Anesthesia and Intensive Care, IRCCS San Raffaele Scientific Institute, Via Olgettina 60, 20132 Milano, Italy. ${ }^{2}$ Australian and New Zealand Intensive Care Research Centre (ANZIC-RC), School of Public Health and

Preventive Medicine, Monash University, Melbourne, Australia. ${ }^{3}$ Department of Critical Care Medicine, Hospital Israelita Albert Einstein, Sao Paulo, Brazil.

${ }^{4}$ Department of Intensive Care, Austin Hospital, Melbourne, Australia.

${ }^{5}$ Department of Intensive Care, Royal Melbourne Hospital, Melbourne, Australia. ${ }^{6}$ Centre for Integrated Critical Care, School of Medicine, The University of Melbourne, Melbourne, Australia.

Received: 21 April 2020 Accepted: 27 April 2020

Published online: 15 May 2020

\section{References}

1. Arentz M, Yim E, Klaff L, Lokhandwala S, Riedo FX, Chong M, et al. Characteristics and outcomes of 21 critically ill patients with COVID-19 in Washington state. JAMA. 2020. https://doi.org/10.1001/jama.2020.4326. [Epub ahead of print].

2. Khanna A, English SW, Wang XS, Ham K, Tumlin J, Szerlip H, et al. Angiotensin II for the treatment of vasodilatory shock. N Engl J Med. 2017; 377(5):419-30.

3. Bellomo R, Wunderink RG, Szerlip H, English SW, Busse LW, Deane AM, et al. Angiotensin I and angiotensin II concentrations and their ratio in catecholamine-resistant vasodilatory shock. Crit Care. 2020;24(1):43.

4. Busse LW, Chow JH, McCurdy MT, Khanna AK. COVID-19 and the RAAS - a potential role for angiotenin II? Crticial Cre. 2020;24:136-40.

5. Patel AB, Verma A. COVID-19 and Angiotensin-Converting Enzyme Inhibitors and Angiotensin Receptor Blockers: What is the Evidence? JAMA.2020. https://doi.org/10.1001/jama.2020.4812. [Epub ahead of print].

\section{Publisher's Note}

Springer Nature remains neutral with regard to jurisdictional claims in published maps and institutional affiliations.

Ready to submit your research? Choose BMC and benefit from:

- fast, convenient online submission

- thorough peer review by experienced researchers in your field

- rapid publication on acceptance

- support for research data, including large and complex data types

- gold Open Access which fosters wider collaboration and increased citations

- maximum visibility for your research: over $100 \mathrm{M}$ website views per year

At $\mathrm{BMC}$, research is always in progress.

Learn more biomedcentral.com/submissions 